\title{
Front Matter: Volume 10223
}

, "Front Matter: Volume 10223," Proc. SPIE 10223, Real-Time Image and Video Processing 2017, 1022301 (19 May 2017); doi: 10.1117/12.2281084

SDIE Event: SPIE Commercial + Scientific Sensing and Imaging, 2017, Anaheim, SPIE. CA, United States 


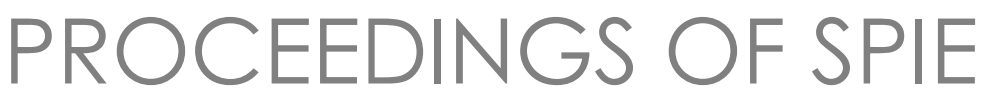

\title{
Real-Time Image and \\ Video Processing 2017
}

\author{
Nasser Kehtarnavaz \\ Matthias F. Carlsohn \\ Editors
}

10-11 April 2017

Anaheim, California, United States

Sponsored and Published by

SPIE 
The papers in this volume were part of the technical conference cited on the cover and title page. Papers were selected and subject to review by the editors and conference program committee. Some conference presentations may not be available for publication. Additional papers and presentation recordings may be available online in the SPIE Digital Library at SPIEDigitallibrary.org.

The papers reflect the work and thoughts of the authors and are published herein as submitted. The publisher is not responsible for the validity of the information or for any outcomes resulting from reliance thereon.

Please use the following format to cite material from these proceedings:

Author(s), "Title of Paper," in Real-Time Image and Video Processing 2017, edited by Nasser Kehtarnavaz, Matthias F. Carlsohn, Proceedings of SPIE Vol. 10223 (SPIE, Bellingham, WA, 2017) Seven-digit Article CID Number.

ISSN: 0277-786X

ISSN: 1996-756X (electronic)

ISBN: 9781510609471

ISBN: 9781510609488 (electronic)

Published by

SPIE

P.O. Box 10, Bellingham, Washington 98227-0010 USA

Telephone +1 3606763290 (Pacific Time) · Fax +1 3606471445

SPIE.org

Copyright @ 2017 , Society of Photo-Optical Instrumentation Engineers.

Copying of material in this book for internal or personal use, or for the internal or personal use of specific clients, beyond the fair use provisions granted by the U.S. Copyright Law is authorized by SPIE subject to payment of copying fees. The Transactional Reporting Service base fee for this volume is $\$ 18.00$ per article (or portion thereof), which should be paid directly to the Copyright Clearance Center (CCC), 222 Rosewood Drive, Danvers, MA 01923. Payment may also be made electronically through CCC Online at copyright.com. Other copying for republication, resale, advertising or promotion, or any form of systematic or multiple reproduction of any material in this book is prohibited except with permission in writing from the publisher. The CCC fee code is 0277-786X/17/\$18.00.

Printed in the United States of America.

Publication of record for individual papers is online in the SPIE Digital Library.

\section{SPIE. DIGITAL}

Paper Numbering: Proceedings of SPIE follow an e-First publication model. A unique citation identifier (CID) number is assigned to each article at the time of publication. Utilization of CIDs allows articles to be fully citable as soon as they are published online, and connects the same identifier to all online and print versions of the publication. SPIE uses a seven-digit CID article numbering system structured as follows:

- The first five digits correspond to the SPIE volume number.

- The last two digits indicate publication order within the volume using a Base 36 numbering system employing both numerals and letters. These two-number sets start with 00, 01, 02, 03, 04, 05, 06, 07, 08, 09, OA, OB ... OZ, followed by 10-1Z, 20-2Z, etc. The CID Number appears on each page of the manuscript. 


\title{
Contents
}

\author{
$\checkmark$ Authors \\ vii Conference Committee
}

REAL-TIME ALGORITHMS AND SYSTEMS

1022302 Structured learning via convolutional neural networks for vehicle detection [10223-1]

1022304 Real-time crowd safety and comfort management from CCTV images [10223-3]

1022305 Real-time text extraction based on the page layout analysis system [10223-4]

1022306 A comparison study between MLP and convolutional neural network models for character recognition [10223-5]

1022307 Weighted fusion of depth and inertial data to improve view invariance for real-time human action recognition [10223-6]

REAL-TIME VIDEO PROCESSING

10223 OA Dual field combination for unmanned video surveillance [10223-11]

10223 OB High bandwidth, real-time video transport with ARINC 818 [10223-12]

10223 OC Real time video analysis to monitor neonatal medical condition [10223-13]

\section{REAL-TIME VIDEO CODING}

10223 OE Pre-processing techniques to improve HEVC subjective quality [10223-15]

10223 OF Beyond the High Efficiency Video Coding standard: an overview [10223-16]

10223 OG An efficient HW and SW design of H.264 video compression, storage and playback on FPGA devices for handheld thermal imaging systems [10223-17]

\section{REAL-TIME VIDEO PROCESSING II}

10223 Ol Camera network video summarization [10223-19]

10223 OJ Low complexity scheme with JPEG-LS for near-lossless, multi-component and selective compression [10223-20] 
POSTER SESSION

10223 OK Parallel halftoning technique using dot diffusion optimization [10223-21]

$10223 \mathrm{OL} \quad$ Parallel steganography framework for hiding a color image inside stereo images [10223-22]

10223 OM Information fusion based techniques for HEVC [10223-23]

10223 ON Real-time depth processing for embedded platforms [10223-24] 


\title{
Authors
}

Numbers in the index correspond to the last two digits of the six-digit citation identifier (CID) article numbering system used in Proceedings of SPIE. The first four digits reflect the volume number. Base 36 numbering is employed for the last two digits and indicates the order of articles within the volume. Numbers start with 00, 01, 02, 03, 04, 05, 06, 07, 08, 09, 0A, 0B...0Z, followed by 10-1Z, 20-2Z, etc.

\author{
Akil, M., 05, 06 \\ Baqui, Muhammad, 04 \\ Ben Driss, S., 06 \\ Benchekroun, A., 05 \\ Botella, Guillermo, OE, OM \\ Chen, Chen, 07 \\ Cruz-Ramos, Clara, OK, OL \\ Del Barrio, A. A., OE, OM \\ del Blanco, Carlos R., 02 \\ Fernández, D. G., OE, OM \\ García, Narciso, 02 \\ Grecos, Christos, OE, OF, OM \\ Gunay, Omer, OG \\ Hao, Huiyan, 07 \\ Hueber, Nicolas, OA \\ Indic, Premananda, OC \\ Jafari, Roozbeh, 07 \\ Jaureguizar, Fernando, 02 \\ Kachouri, R., 05, 06 \\ Kamisli, Fatih, OG \\ Kehtarnavaz, Nasser, 07 \\ Löhner, Rainald, 04 \\ Makarov, Aleksej, ON \\ Manzanera, Antoine, OA \\ Maqueda, Ana I., 02 \\ Mert, Yakup Murat, 0J \\ Meyer-Baese, Anke, OE, OM \\ Meyer-Baese, Uwe, OE, OM \\ Molina-Garcia, Javier, OK \\ Munoz-Ramirez, David O., OL \\ Ozsarac, Ismail, OG \\ Panda, Rameswar, 01 \\ Paydarfar, David, OC \\ Perrot, Maxime, OA \\ Ponomaryov, Volodymyr I., OK, OL \\ Rahnama, Oscar, ON \\ Raymond, Pierre, OA \\ Reyes-Reyes, Rogelio, OK, OL \\ Roy-Chowdhury, Amit K., Ol \\ Sarrabezolles, Lovise, OA \\ Shirvaikar, Mukul, OC \\ Soua, M., 05, 06 \\ Torr, Philip, ON \\ Zimmerman, Michael, OB
}


Proc. of SPIE Vol. 10223 1022301-6

Downloaded From: https://www.spiedigitallibrary.org/conference-proceedings-of-spie on 26 Apr 2023 Terms of Use: https://www.spiedigitallibrary.org/terms-of-use 


\section{Conference Committee}

Symposium Chair

Majid Rabbani, Rochester Institute of Technology (United States)

Symposium Co-chair

Robert Fiete, Harris Corporation (United States)

Conference Chairs

Nasser Kehtarnavaz, The University of Texas at Dallas (United States)

Matthias F. Carlsohn, Computer Vision and Image Communication at Bremen (Germany)

Conference Program Committee

Mohamed Akil, ESIEE Paris (France)

Guillermo Botella, Universidad Complutense de Madrid (Spain)

Ahmed Bouridane, Northumbria University (United Kingdom)

Philip P. Dang, U.S. Deptartment of Commerce (United States)

Touradj Ebrahimi, Ecole Polytechnique Fédérale de Lausanne (Switzerland)

Barak Fishbain, Technion-Israel Institute of Technology (Israel)

Christos Grecos, Central Washington University (United States)

Reinhard Koch, Christian-Albrechts-Universität zu Kiel (Germany)

J. A. Madeiras Pereira, INESC-ID (Portugal)

Volodymyr Ponomaryov, Instituto Politécnico Nacional (Mexico)

Luis Salgado, Universidad Politécnica de Madrid (Spain)

Sergio Saponara, Università di Pisa (Italy)

Mukul V. Shirvaikar, The University of Texas at Tyler (United States)

Athanassios N. Skodras, University of Patras (Greece)

Bogdan Smolka, Silesian University of Technology (Poland)

Stephan C. Stilkerich, Airbus Group Innovations (Germany)

Lennart Wietzke, Raytrix GmbH (Germany)

\section{Session Chairs}

1 Real-time Algorithms and Systems

Mukul V. Shirvaikar, The University of Texas at Tyler (United States)

2 Real-time Hardware Implementation

Mohamed Akil, ESIEE Paris (France) 
3 Real-time Video Processing

Nasser Kehtarnavaz, The University of Texas at Dallas (United States)

4 Real-time Video Coding

Christos Grecos, Central Washington University (United States)

5 Real-Time Video Processing II

Christos Grecos, Central Washington University (United States) 